\title{
DISCRETE MODEL OF CHAIN CONVEYOR MOVEMENT DYNAMICS
}

\author{
M. M. Korobko \\ National University of Life and Environmental Sciences of Ukraine, Ukraine. \\ Speciality of article: 133 - industry engineering. \\ Corresponding author: korobko_mm@nubip.edu.ua.
}

Article history: Received-August 2020, Accepted-October 2020.

Bibl. 14, fig. 2, tabl. 0.

\begin{abstract}
Improving the reliability of structures of transport mechanisms and other elements, reducing metal content, improving performance, expanding functionality and technical capabilities is a priority area of work to improve existing and develop new machines for beet growing. The dynamic model of the chain conveyor which considers the basic movement and fluctuations of elements of the drive and a working cloth is developed in work. The model is represented by a system of discrete masses with eight degrees of freedom.

The operation of chain conveyors is characterized by the presence of dynamic forces arising from the pulsating movement of the chain at a steady rotation of the drive sprocket. At the start-up site, dynamic forces from increasing the speed from zero to a certain constant value are added to these forces. Under such conditions, significant alternating dynamic loads can occur in the chain, which as a result of the accumulation of fatigue phenomena can lead to its premature destruction.
\end{abstract}

Key words: conveyor, weight, model.

\section{Introduction}

In the existing theoretical and experimental researches of rod conveyors their constructive parameters, productivity, damage of root tubers and separating ability are proved. However, not enough attention is paid to the study of current dynamic loads, their nature of change over time and the impact on the drive elements of the conveyors, the working canvas and root damage.

During unstable operating modes, the traction elements, as well as the drive elements are under the action of dynamic loads. The greatest dynamic loads occur when starting the conveyor, its output at operating speeds, as well as when stopping or jamming the web. Such loads are undesirable and are significant factors that accelerate the wear of the conveyor belt and drive elements, as well as affect the damage to the roots when interacting with the working elements of the conveyors.

The study of dynamic processes in the operation of conveyors is an urgent task, the solution of which will assess the dynamic loads acting on its elements and drive during transients, as well as on this basis to modernize existing structures and develop new ones that will ensure high efficiency of beet harvesters.

The dynamics of the movement of chain conveyors are characterized by variable oscillating loads during transients and after the exit of the conveyor to steady state. The study of these loads makes it possible to determine the most favorable modes of movement of the conveyor during start-up.

\section{Formulation of problem}

The practice of operation of root harvesting machines confirms that about $30 \%$ of all failures are on conveyor belts. Conveyors of some machines sometimes do not provide even seasonal operation and need to be repaired or replaced during operation [1]. During unstable operating modes, the traction elements as well as the drive elements are under dynamic load. It is known that significant dynamic loads are observed when starting the conveyor, its output at operating speeds, as well as when stopping or jamming the web [2]. Significant dynamic loads are an undesirable phenomenon and are among the significant factors that accelerate the operation of the conveyor belt and drive elements.

During the start-up of the chain conveyor in the traction link of the web there are dynamic loads, the magnitude of which mainly depends on the excess force or duration of start-up. Under the action of pulses that create acceleration, small elastic oscillations occur in the elements of the system. The latter lead to an increase in inertial loads in comparison with their average values, which are determined by the laws of motion of an absolutely rigid body. In the conditions of inconsistency of speeds of all or some elements of the car such sizes, as duration of the periods of start (acceleration) and braking, overload of the engine and transfers, can be defined only on the basis of dynamic calculations at which both instability of speed during movement, and inertia of masses, involved in the movement process

The aim of the work is to increase the efficiency of chain conveyor by reducing the dynamic loads acting on the drive elements of the bar conveyor and the working bodies of the canvas. 


\section{Analysis of recent research results}

A significant number of works by domestic and foreign scientists are devoted to the study of conveyors with a chain traction body. The main attention is paid to the issues of wear and strength of the chain traction body, the theory and calculation of chain engagement, kinematic and dynamic calculation, as well as the development of new structural schemes of conveyors operating in a steady state.

Studies of the dynamic processes of the conveyor are carried out by using different research models. The application and use of dynamic models to calculate the loads of conveyors and their drives are considered in many works, for example [3, 4, 5]. However, these works did not take into account the modes of operation of the drive, which affect the uneven movement of the blade, which in turn accelerates the speed of the mechanism as a whole [6$14]$.

\section{Purpose of research}

During transients (start, stop), as well as in the area of steady motion in the structural elements and the drive there are significant dynamic loads, which can be several times higher than the average static loads.

The purpose of the work is to increase the efficiency of chain conveyors by reducing the dynamic loads acting on the drive elements and the working bodies of the chain conveyors.

\section{Results of research}

It is advisable to take into account the dynamic calculations the influence of the drive on the characteristics of the closed circuit of the conveyor belt. Therefore, this work aims to develop a dynamic model of the bar conveyor, which simultaneously takes into account the nature of the movement of the drive mechanism and the working canvas with the transported cargo. A dynamic model of a bar conveyor is proposed, which takes into account both the dynamics of the drive and the dynamics of the working web, taking into account the elastic properties of their individual elements. In this dynamic model (Fig. 1) the bar conveyor is presented as a holonomic mechanical system with eight degrees of freedom $(n=8)$ of discrete rotating $I_{1}, I_{2}, I_{3}$, and $I_{7}$ and translational $\mathrm{m}_{4}, \mathrm{~m}_{5}, \mathrm{~m}_{6}$, and $\mathrm{m}_{8}$ masses. Here $\mathrm{I}_{1}, \mathrm{I}_{2}, \mathrm{I}_{3}, \mathrm{I}_{7}$ moments of inertia, respectively, of the rotor of the drive motor, the rotating parts of the gearbox, the drive shaft with sprockets, reduced to the axis of the drive shaft and the guide rollers relative to its own axis. The working branch of the conveyor is represented by three discrete masses $\mathrm{m}_{4}$, $\mathrm{m}_{5}, \mathrm{~m} 6$ connected to each other and asterisks by elastic elements with stiffness $\mathrm{C}_{34}, \mathrm{C}_{45}, \mathrm{C}_{56}, \mathrm{C}_{67}$, and the idle (nonworking) branch is replaced by one mass $\mathrm{m}_{8}$ which is connected to asterisks and guides. Rollers elastic elements with stiffness $\mathrm{C}_{78}$ and $\mathrm{C}_{83}$. The motor shaft is connected to the input shaft of the gearbox via a power take-off shaft with a stiffness $\mathrm{C}_{12}$, and its output shaft is connected via a resilient safety coupling with a stiffness $C_{23}$ to the drive shaft.

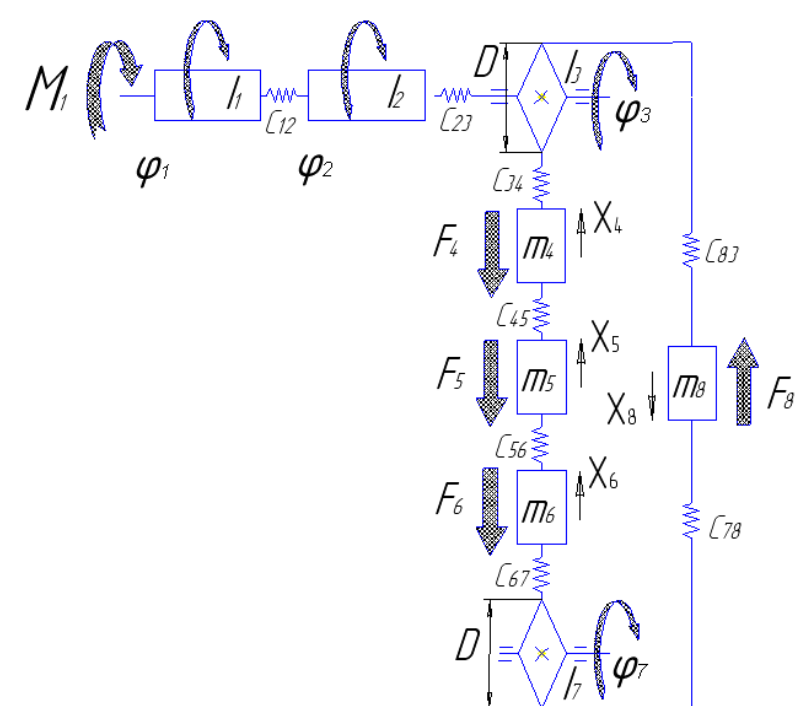

Fig. 1. Dynamic model of a chain conveyor.

The generalized coordinates of the proposed dynamic model are: $\mathrm{q}_{1}=\varphi_{1}, \mathrm{q}_{2}=\varphi_{2}, \mathrm{q}_{3}=\varphi_{3}$ and $\mathrm{q}_{7}=\varphi_{7}$ are the rotational coordinates of the drive motor rotor, the reduced mass of the gearbox, the drive shaft and the guide rollers of the conveyor; $\mathrm{q}_{4}=\mathrm{x}_{4}, \mathrm{q}_{5}=\mathrm{x}_{5}, \mathrm{q}_{6}=\mathrm{x}_{6}$ and $\mathrm{q}_{8}=\mathrm{x}_{8}-$ translational coordinates of the respective masses $m_{4}, m_{5}$, $\mathrm{m}_{6}$ and $\mathrm{m}_{8}$ into which the branches of the working and idle part of the canvas are divided.

To compile the differential equations of motion of the conveyor, the Lagrange equation of the second kind is used

$$
\frac{d}{d t} \frac{d L}{\partial \dot{q}_{k}}-\frac{\partial L}{\partial q_{k}}=Q_{k}, \mathrm{k}=1,2, \ldots . \mathrm{n} ;
$$

where $\mathrm{t}$ is the time; $\mathrm{L}=\mathrm{T}-\mathrm{P}$ - Lagrange function; $\mathrm{T}, \mathrm{P}$ kinetic and potential energy of the conveyor; $\mathrm{q}_{\mathrm{k}}-(\mathrm{k}=1,2$, .. 8) generalized coordinate of the system; $Q_{k}$ is a generalized force.

The kinetic energy of the system is represented as the sum of rotational $\mathrm{T}_{\text {об }}$ and translational $\mathrm{T}_{\text {пост }}$ masses

$$
\begin{gathered}
\mathrm{T}=\mathrm{T}_{\text {об}}+\mathrm{T}_{\text {пост }}= \\
\frac{1}{2} I_{1} \dot{\varphi}_{1}+\frac{1}{2} I_{2} \dot{\varphi}_{2}+\frac{1}{2} I_{3} \dot{\varphi}_{3}+\frac{1}{2} I_{7} \dot{\varphi}_{7}+\frac{1}{2} m_{4} \dot{x}_{4}+\frac{1}{2} m_{5} \dot{x}_{5}+\frac{1}{2} m_{6} \dot{x}_{6}+\frac{1}{2} m_{8} \dot{x}_{8} .
\end{gathered}
$$

Potential energy is defined as the deformation energy of the elastic parts of the conveyor

$$
\begin{aligned}
& \Pi=\frac{1}{2} C_{12}\left(\varphi_{1}-\varphi_{2}\right)^{2}+\frac{1}{2} C_{23}\left(\varphi_{2}-\varphi_{3}\right)^{2}+\frac{1}{2} C_{34}\left(\frac{D}{2} \varphi_{3}-x_{4}\right)^{2}+ \\
& +\frac{1}{2} C_{45}\left(x_{4}-x_{5}\right)^{2}+\frac{1}{2} C_{56}\left(x_{5}-x_{6}\right)^{2}+\frac{1}{2} C_{67}\left(x_{6}-\frac{D}{2} \varphi_{7}\right)^{2}+ \\
& +\frac{1}{2} C_{78}\left(\frac{D}{2} \varphi_{7}-x_{8}\right)^{2}+\frac{1}{2} C_{83}\left(x_{8}-\frac{D}{2} \varphi_{3}\right)^{2}
\end{aligned}
$$

Generalized forces (4)

$$
\begin{gathered}
Q_{1}=M_{1}+\frac{\partial \Pi}{\partial \varphi_{1}}=M_{1}-C_{12}\left(\varphi_{1}-\varphi_{2}\right) ; \\
Q_{2}=\frac{\partial \Pi}{\partial \varphi_{2}}=C_{12}\left(\varphi_{1}-\varphi_{2}\right)-C_{23}\left(\varphi_{2}-\varphi_{3}\right) ; \\
Q_{3}=\frac{\partial \Pi}{\partial x_{3}}=C_{23}\left(\varphi_{2}-\varphi_{3}\right)-C_{34}\left(\frac{D}{2} \varphi_{3}-x_{4}\right) \frac{D}{2}+C_{83}\left(x_{8}-\frac{D}{2} \varphi_{3}\right) \frac{D}{2} ; \\
Q_{4}=-F_{4}+\frac{\partial \Pi}{\partial x_{4}}=-F_{4}+C_{34}\left(\frac{D}{2} \varphi_{3}-x_{4}\right) \frac{D}{2}-C_{45}\left(x_{4}-x_{5}\right) ; \\
Q_{5}=-F_{5}+\frac{\partial \Pi}{\partial x_{5}}=-F_{5}+C_{45}\left(x_{4}-x_{5}\right)-C_{56}\left(x_{5}-x_{6}\right) ; \\
Q_{6}=-F_{6}+\frac{\partial \Pi}{\partial x_{6}}=-F_{6}+C_{56}\left(x_{5}-x_{6}\right)-C_{67}\left(x_{6}-\frac{D}{2} \varphi_{7}\right) \frac{D}{2} ;
\end{gathered}
$$




$$
\begin{gathered}
Q_{7}=\frac{\partial \Pi}{\partial \varphi_{7}}=C_{67}\left(x_{6}-\frac{D}{2} \varphi_{7}\right) \frac{D}{2}-C_{78}\left(\frac{D}{2} \varphi_{7}-x_{8}\right) \frac{D}{2} ; \\
Q_{8}=-F_{8}+\frac{\partial \Pi}{\partial x_{8}}=-F_{8}+C_{78}\left(\frac{D}{2} \varphi_{7}-x_{8}\right) \frac{D}{2}-C_{83}\left(x_{8}-\frac{D}{2} \varphi_{3}\right) \frac{D}{2},
\end{gathered}
$$

where $\mathrm{M}_{1}$ is the driving moment of the motor drive, reduced to the axis of the drive shaft; $\mathrm{F}_{4}, \mathrm{~F}_{5}, \mathrm{~F}_{6}, \mathrm{~F}_{8}$ - forces of resistance to movement, respectively, the masses $\mathrm{m}_{4}, \mathrm{~m}_{5}$, $\mathrm{m}_{6}$ and $\mathrm{m}_{8} ; \mathrm{D}$ is the diameter of the star.

After substituting the kinetic (2) and potential energy (3) of the conveyor and the generalized forces (4) in equation (1) we obtain a system of differential equations of motion of the conveyor (5):

$$
\begin{aligned}
& I_{1} \ddot{\varphi}_{1}=M_{1}-C_{12}\left(\varphi_{1}-\varphi_{2}\right) ; \\
& I_{2} \ddot{\varphi}_{2}=C_{12}\left(\varphi_{1}-\varphi_{2}\right)-C_{23}\left(\varphi_{2}-\varphi_{3}\right) ; \\
& I_{3} \ddot{\varphi}_{3}=C_{23}\left(\varphi_{2}-\varphi_{3}\right)-C_{34}\left(\frac{D}{2} \varphi_{3}-x_{4}\right) \frac{D}{2}+C_{83}\left(x_{8}-\frac{D}{2} \varphi_{3}\right) \frac{D}{2} ; \\
& m_{4} \ddot{x}_{4}=-F_{4}+C_{34}\left(\frac{D}{2} \varphi_{3}-x_{4}\right) \frac{D}{2}-C_{45}\left(x_{4}-x_{5}\right) ; \\
& m_{5} \ddot{x}_{5}=-F_{5}+C_{45}\left(x_{4}-x_{5}\right)-C_{56}\left(x_{5}-x_{6}\right) ; \\
& m_{6} \ddot{x}_{6}=-F_{6}+C_{56}\left(x_{5}-x_{6}\right)-C_{67}\left(x_{6}-\frac{D}{2} \varphi_{7}\right) \frac{D}{2} ; \\
& I_{7} \ddot{\varphi}_{7}=C_{67}\left(x_{6}-\frac{D}{2} \varphi_{7}\right) \frac{D}{2}-C_{78}\left(\frac{D}{2} \varphi_{7}-x_{8}\right) \frac{D}{2} ; \\
& m_{8} \ddot{x}_{8}=-F_{8}+C_{78}\left(\frac{D}{2} \varphi_{7}-x_{8}\right) \frac{D}{2}-C_{83}\left(x_{8}-\frac{D}{2} \varphi_{3}\right) \frac{D}{2} .
\end{aligned}
$$

These equations can be used to describe dynamic processes in the elements of the conveyor both in the areas of transients (start, braking) and in the area of steady motion.

Different initial motion conditions can be used to solve equations (5) depending on the section of motion. For example, the process of starting from the standstill of the conveyor includes several stages.

The first stage is performed by rotating the mass with the moment of inertia $\mathrm{I} 1$ from the time $\mathrm{t}=0$ at $\varphi_{1}=0$ and $\dot{\varphi}_{1}=0$ to the moment $\mathrm{t}=\mathrm{t}_{1}$, at which the elastic force between the masses $I_{1}$ and $I_{2}$ with the driving moment $M_{1}$ is balanced. At this point, the coordinate $\varphi_{1}$ will reach the value $\varphi_{11}=\mathrm{M}_{1} / \mathrm{C}_{12}$, which will be the initial condition for the second stage of start-up. At this stage, only the first equation of system (5) is used, provided that the coordinate $\varphi_{2}=0$ during the entire period of motion of the first mass.

The second stage - rotating masses $I_{1}$ and $I_{2}$ with all other masses stationary from the time $\mathrm{t}=\mathrm{t}_{1}$ at $\varphi_{1}=\varphi_{11}, \varphi_{1}$ $=\dot{\varphi}_{11}, \varphi_{2}=0$ and $\dot{\varphi}_{2}=0$ to the moment $t_{2}$, at which the elastic force between the masses $I_{2}$ and $I_{3}$ is balanced with driving moment $\mathrm{M}_{1}$. At this moment, the coordinate $\varphi_{1}$ will reach the value $\varphi_{12}$, the coordinate $\varphi_{2}=\varphi_{22}$, and their derivatives $\dot{\varphi}_{1}^{\prime}=\dot{\varphi}_{12}$, and $\dot{\varphi}_{2}=\dot{\varphi}_{22}$. Here $\varphi_{12}, \varphi 22, \dot{\varphi}_{12}, \dot{\varphi}_{22}$ are the final values of the coordinates $\varphi_{1}$ and $\varphi_{2}$ and their velocities of the second stage of start-up, which are the initial conditions of the third stage of start-up. In the second stage of start-up, a system of the first two differential equations of system (5) is used. During the entire second stage of start-up, the coordinate $\varphi_{3}=0$.

Similarly, the initial conditions of motion for all other masses of the adopted model of the conveyor are determined. To do this, in addition to the considered stages, it is necessary to consider the stages of the beginning of the movement from the third to the eighth mass. The start-up process ends at the time when the working line of the conveyor (masses $\mathrm{m}_{4}, \mathrm{~m}_{5}, \mathrm{~m}_{6}$ ) reaches a stable value of the steady speed.

The operation of chain conveyors is characterized by the presence of dynamic forces arising from the pulsating movement of the chain with a steady rotation of the drive sprocket [6]. At the start-up site, dynamic forces from a speed increase from zero to a certain constant value are added to these forces. Under such conditions, the chain may experience significant alternating dynamic loads, which as a result of the accumulation of fatigue phenomena can lead to its premature destruction.

Therefore, the aim of this work is to determine such a mode of start of the chain conveyor, in which the total dynamic force in the chain would be minimal.

The total force $F$ acting on the chain consists of a static component $F_{c}$, which is a constant value and does not depend on the mode of movement of the conveyor and a dynamic component $F_{d}$, which is a variable function depending on the parameters of the sprocket and chain and the mode of movement of the drive mechanism.

$$
F=F_{c}+F_{\partial} \text {. }
$$

The static component $F_{c}$ includes: 1$)$ resistance on the supporting rollers; 2) resistance to friction forces in the supports of the stars; 3 ) resistance to chain stiffness during bending. These components of resistance are determined by known methods [6] and in practical calculations are not in doubt.

The dynamic component is greater the greater the length of the chain link and its speed, the smaller the number of teeth of the drive sprocket and the greater the moving weight of the load and the conveyor itself. These loads increase the effort in the traction body and, as a result of repeated application, cause fatigue in the chains. The dynamic component of the force in the traction body can be determined by the dependence [7].

$$
F_{\partial}=m W_{L}
$$

where $m$ is the consolidated mass of the moving elements of the bar conveyor and cargo [7];

$\mathrm{W}_{\mathrm{L}}$ - linear acceleration of the traction body of the chain.

According to the method described in [7], the consolidated mass $\mathrm{m}$ is determined by the dependence

$$
m=\left(q_{b}+\psi q_{0}\right) L,
$$

where $\mathrm{q}_{\mathrm{B}}$ - running weight of the cargo; $\mathrm{q}_{0}$ is the running mass of the moving parts of the conveyor; $\mathrm{L}$ is the length of the conveyor; $\psi$ is the coefficient of mass reduction, which takes into account the fact that not the entire mass of the conveyor moves with the acceleration $\mathrm{W}_{\mathrm{L}}$, and also takes into account the influence of elasticity and sagging of the chain.

To determine the acceleration of the chain $\mathrm{W}_{\mathrm{L}}$, consider the scheme of interaction of the latter with the asterisk (Fig. 2). Asterisk 5 rotates with an angular velocity $\omega$, and its circular velocity is determined by a known dependence

$$
V=\omega R \text {, }
$$

where $\mathrm{R}$ is the initial radius of the asterisk; $\omega$ is the angular velocity of the asterisk.

Then the horizontal component of the chain speed changes according to the law 


$$
V_{L}=V \cos \varphi=\omega R \cos \varphi,
$$

here $\varphi$ is the angular coordinate of the rotation of the star between adjacent teeth, which is calculated from the bisector of the angle between the teeth and varies from - $\varphi_{0}$ to $\varphi_{0}$, ie $-\varphi_{0} \leq \varphi \leq \varphi_{0}$. The central angle between the teeth can be determined by the dependence $2 \varphi_{0}=2 \pi / z$, where $\mathrm{z}$ is the number of teeth of the leading star. Then $\varphi_{0}=\pi / \mathrm{z}$.

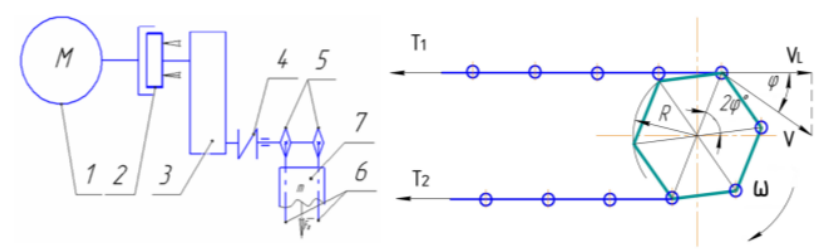

Fig. 2. Circuit conveyor drive scheme: 1 - engine; 2 clutch; 3 - reducer; 4 - safety clutch; 5 - sprockets with a drive shaft; 6 - traction chains; 7 - conveyor belt.

The angular coordinate of the asterisk $\alpha$ is divided into $\mathrm{n}$ sections. At the zero section $0 \leq \alpha \leq 2 \varphi_{0}$. In this case, $\varphi_{0} \leq \varphi \leq \varphi_{0}$. In the first section $2 \varphi_{0} \leq \alpha \leq 4 \varphi_{0}$, and $--\varphi_{0} \leq \varphi \leq \varphi_{0}$. In the $\mathrm{k}$-th section, the angular coordinates $\alpha$ and $\varphi$ change within the following limits

$2 k \varphi_{0} \leq \alpha \leq 2(k+1) \varphi_{0} ;-\varphi_{0} \leq \varphi \leq \varphi_{0}, k=0,1,2, \ldots ., n . \quad$ (11)

Taking the time derivative of the dependence (10), we determine the law of change of the linear acceleration of the chain

$$
\begin{aligned}
& \text { If } \frac{d \varphi}{d t}=\omega \begin{array}{l}
W_{L}=\frac{d V_{L}}{d t}=\frac{d \omega}{d t} R \cos \varphi-\omega \frac{d \varphi}{d t} R \sin \varphi \\
W_{L}=R\left(\frac{d \omega}{d t} \cos \varphi-\omega^{2} \sin \varphi\right)
\end{array}
\end{aligned}
$$

The analysis of the dependence (13) shows that to determine the acceleration of the chain it is necessary to know the law of motion of the leading sprocket (Fig. 2) in all areas of motion during the start of the conveyor.

To determine this law of motion, it is necessary to solve the second problem of the dynamics of conveyor motion. To do this, in the first approximation, we consider the pipeline as a dynamic model with a nonlinear position function (the relationship between the kinematic characteristics of the drive sprocket and the chain is nonlinear) and one degree of freedom. For the generalized coordinate we take the coordinate of the rotation of the star between adjacent teeth on the $\mathrm{k}$-th $(\mathrm{k}=0,1,2, \ldots, \mathrm{n})$ section of the rotation of the star.

This model does not take into account the elasticity and sagging of the chain, because they are indirectly taken into account by the coefficient $\psi$ in the total mass of the moving parts of the conveyor, which is determined by the dependence (9).

We compose the equation of motion of such a dynamic conveyor model for each section of motion using the theorem on the change of kinetic energy [8].

$$
T-T_{0}=A_{p}-A_{0},
$$

where $\mathrm{T}_{0}, \mathrm{~T}$ - functions of the kinetic energy of the system at the beginning of motion and at a certain point in time; Ap, $\mathrm{A}_{0}$ - work of driving forces of the drive and forces of resistance to movement of the conveyor on the considered site of movement.

Dependence functions (14) have the following form:

$$
\begin{gathered}
T_{0}=\frac{1}{2} I_{p}\left(-\varphi_{0}\right) \omega_{0}^{2} ; \quad T=\frac{1}{2} I_{p}(\varphi) \omega^{2}, \\
A_{p}=\int_{-\varphi_{0}}^{\varphi} M d \varphi \quad A_{0}=\int_{-\varphi_{0}}^{\varphi} F_{0} R \cos \varphi d \varphi
\end{gathered}
$$

where, Ip $\left(-\varphi_{0}\right)$, Ip $(\varphi)$ - reduced to the axis of rotation of the drive star moments of inertia of the moving parts of the conveyor in the initial position and at any time; $\omega_{0}$ is the angular velocity of the asterisk in the initial position.

$\mathrm{M}$ is the driving moment of the drive, reduced to the axis of rotation of the drive sprocket; $F_{0}$ is the total resistance of the static forces of resistance to the movement of the web.

Substituting the dependences (15) and (16) in equation (14) and taking from the left and right parts of this equality derivatives in the coordinate $\varphi$, we obtain the law of motion of the chain conveyor in the form of differential equations [9]:

$$
\begin{gathered}
I_{p} \frac{d \omega}{d \varphi}+\frac{1}{2} \omega \frac{d I_{p}(\varphi)}{d \varphi}=\frac{1}{\omega}\left(M-F_{0} R \cos \varphi\right) \\
I_{p}=I_{0}+m R^{2} \cos ^{2} \varphi
\end{gathered}
$$

where $I_{0}$ is the moment of inertia of the rotor of the engine 1 , the clutch 2 , the gearbox 3 , the elastic clutch 4 and the drive shaft with sprockets 5 reduced to the axis of rotation of the sprocket (see Fig. 2).

Equation (17) taking into account the dependence (18) is a nonlinear differential equation of the first order with variable coefficients and a complex right-hand side. Such equations cannot be analytically integrated, so numerical methods must be used to solve them. To use the finite difference method [8], equation (17) is presented as follows

$$
I_{p}(\varphi) d \omega+\frac{1}{2} \omega d I_{p}(\varphi)=\frac{1}{\omega}\left(M-F_{0} R \cos \varphi\right) d \varphi
$$

Divide the conveyor interval $-\varphi_{0} \leq \varphi \leq \varphi_{0}$ into $\mathrm{n}$ parts and assume that $-\mathrm{d} \varphi_{0} \approx \Delta \varphi=2 \varphi_{0} / \mathrm{n}$ on each part. Then the coordinate $\varphi_{i}+1=\varphi_{i}+\Delta \varphi$. Here and - the number of the position of the drive star, which varies from 0 to n. For any position of the conveyor $\varphi=\varphi_{\mathrm{i}}$, Ip $(\varphi)=\operatorname{Ip}\left(\varphi_{\mathrm{i}}\right), \omega=\omega_{\mathrm{i}}, \mathrm{M}$ $=\mathrm{M}_{\mathrm{i}}, \mathrm{dI}_{\mathrm{p}}(\varphi) \approx \mathrm{I}_{\mathrm{p}}\left(\varphi_{\mathrm{i}}+1\right)-\mathrm{I}_{\mathrm{p}}\left(\varphi_{\mathrm{i}}\right)$. Substituting these substitutions in equation (19), we obtain (20):

$$
\omega_{i+1}=\frac{1}{I_{p}\left(\varphi_{i}\right)}\left[\frac{1}{\omega_{i}}\left(M_{i}-F_{0} R \cos \varphi_{i}\right) \Delta \varphi+\frac{1}{2}\left[3 I_{p}\left(\varphi_{i}\right)-I_{p}\left(\varphi_{i+1}\right)\right] \cdot \omega_{i}\right]
$$

The movement of the conveyor during start-up begins with the position $\varphi_{i}=-\varphi_{0}$; while $\omega_{i}=\omega_{0}=0$. For this position, $I_{p}\left(\varphi_{i}\right), I_{p}\left(\varphi_{i}+1\right), M_{i}$ are determined and are substituted into the dependence (20), from which $\omega_{i}+1$ are determined. Calculations $\omega_{\mathrm{i}}+1$ are performed until $\varphi_{\mathrm{i}}$ becomes equal to $\varphi_{0}$. Then the calculations are performed for the next section of the movement $2 \varphi_{0} \leq \alpha \leq 4 \varphi_{0}$ with the repetition of all procedures performed on the previous section. Moreover, the initial value of the velocity $\omega_{0}$ in this section is taken to be the value of the velocity found at the end point of the previous section, $\omega_{0}=\omega_{\mathrm{n}}$.

\section{Conclusions}

1. As a result of the solution of the system (5), the coordinates, velocities and accelerations of each of the masses are determined for the found initial conditions of 
motion. With the help of these characteristics the dynamic loads in the elastic elements of the conveyor are determined. The analysis of these loads will allow to establish rational inertial and elastic characteristics of the conveyor and to reach the most favorable mode of the start of the conveyor.

2. The conducted researches allowed to recommend the system of the controlled start of the rod conveyor which gives the chance to reduce considerably dynamic loadings: coefficient of dynamism in 2.4..2.6 times, coefficient of unevenness of movement on 10-15\%, starting moment - in $1.8 \ldots 2.2$ times.

\section{References}

1. Shabelnik B. P. (1998). Conveyors-cleaners of root-harvesting machines. Kyiv. 243.

2. Volkov P. M., Tenenbaum M. M. (1977). Basics of the theory and calculation of agricultural machines for strength and reliability. Moscow. 310.

3. Khorolsky I. M. (1999). Dynamics of chain systems and closed circuits of continuous transport machines. Lviv. 208.

4. Zinoviev V. A., Bessonov A. P. (1964). Fundamentals of dynamics of machine units. Moscow. 239.

5. Kozhevnikov S. N. (1986). Dynamics of nonstationary processes in machines. Kyiv. 288.

6. Kornev G. V. (1968). Continuous lifting and transport machines used in agriculture. Kyiv. 152.

7. Perten Yu. A., Misailov V. K., Yantovsky L. (1981). Theoretical foundations of conveyors with traction elements: Publishing House of Leningrad University. 270.

8. Fedorchenko A. M. (1999). Experimental foundations and mathematical formulation of the fundamental laws of physics. Kyiv. 288.

9. Loveykin V. S., Yaroshenko V. F., Korobko M. M. (2006). Analysis of start-up modes of chain conveyors of agricultural machines. Proceedings of the Tavriya State Agrotechnical Academy. Melitopol. Issue 40. 221-230.

10. Pylypaka S. F., Nesvidomin V. M., Klendii M. B., Rogovskii I. L., Kresan T. A., Trokhaniak V. I. (2019). Conveyance of a particle by a vertical screw, which is limited by a coaxial fixed cylinder. Bulletin of the Karaganda University - Mathematics. 95(3). 108-118. doi 10.31489/2019M2/108-119.

11. Rogovskii I. L., Titova L. L., TrokhaniakV.I., Solomka O. V., $\quad$ Popyk P. S., Shvidia V. O., Stepanenko S. P. (2019). Experimental studies of drying conditions of grain crops with high moisture content in low-pressure environment. INMATEH. Agricultural Engineering. Bucharest. 57(1). 141-146.

12. Loveikin V., Romasevych Y., Shymko L., Ohiienko M., Duczmal W., Potwora W., Titova L., Rogovskii I. (2020). Agrotronics and optimal control of cranes and hoisting machines: monograph. Opole: The Academy of Management and Administration in Opole. 164.

13. Zagurskiy O., Ohiienko M., Pokusa T., Zagurska S., Pokusa F., Titova L., Rogovskii I. (2020). Study of efficiency of transport processes of supply chains management under uncertainty. Monograph. Opole: The
Academy of Management and Administration in Opole. 162.

14. Rogovskii I. L., Titova L. L., TrokhaniakV. I., Rosamaha Yu. O., Blesnyuk O. V., Ohiienko M. M. Ohiienko A. V. (2019). Engineering management of twophase coulter systems of seeding machines for implementing precision farming technologies. INMATEH. Agricultural Engineering. 2019. 58(2). 137-146. doi: 10.35633/INMATEH-58-15.

\section{Список літератури}

1. Шабельник Б. П. Конвееры-очиститетли коренуборочных машин. Київ. Міносвіта, 1998. 243 с.

2. Основы теории и расчета сельскохозяйственных машин на прочность и надежность. Под ред. П. М. Волкова, М. М. Тененбаума. Москва. Машиностроение, 1977. $310 \mathrm{c}$.

3. Хорольський I. M. Динаміка ланцюгових систем і замкнутих контурів машин неперервного транспорту. Львів, 1999. 208 с.

4. Вяч А. 3., Бессонов А. П. Основы динамики машинных агрегатов. Москва. Машиностроение, 1964. 239 c.

5. Кожевников С. Н. Динамика нестационарных процессов в машинах. Київ. Наукова думка, 1986. $288 \mathrm{c}$.

6. Корнєв Г. В. Підйомно-транспортні машини безперервної дії, застосовувані у сільському господарстві. Київ. Урожай, 1968. 152 с.

7. Пертен Ю. А., Мисаилов В. К., Янтовский Л. И. Теоретические основы конвейеров с тяговыми элементами. Изд-во Ленинградского ун-та, 1981. 270 с.

8. Федорченко А. М. Экспериментальные основы и математическая формулировка фундаментальных законов физики. Київ. Вища школа, 1992.88 с.

9. Ловейкін В. С., Ярошенко В. Ф., Коробко М. М. Аналіз режимів пуску ланцюгових конвеєрів сільськогосподарських машин. Праці Таврійської державної агротехнічної академії. Мелітополь, 2006. Вип. 40. С. 221-230.

10. Pylypaka S. F., Nesvidomin V. M., Klendii M. B., Rogovskii I. L., $\quad$ Kresan T. A., $\quad$ Trokhaniak V.I. Conveyance of a particle by a vertical screw, which is limited by a coaxial fixed cylinder. Bulletin of the Karaganda University - Mathematics. 2019. Vol. 95. Issue 3. P. 108-118. doi 10.31489/2019M2/108-119.

11. Rogovskii I. L., Titova L.L., Trokhaniak V.I., Solomka O. V., $\quad$ Popyk P.S., S Shvidia V. O., Stepanenko S. P. Experimental studies of drying conditions of grain crops with high moisture content in low-pressure environment. INMATEH. Agricultural Engineering. Bucharest. 2019. Vol. 57. No 1. P. 141-146.

12. Loveikin V., Romasevych Y., Shymko L., Ohiienko M., Duczmal W., Potwora W., Titova L., Rogovskii I. Agrotronics and optimal control of cranes and hoisting machines: monograph. Opole: The Academy of Management and Administration in Opole. 2020. 164 p.

13. Zagurskiy O., Ohiienko M., Pokusa T., Zagurska S., Pokusa F., Titova L., Rogovskii I. Study of efficiency of transport processes of supply chains management under 
uncertainty. Monograph. Opole: The Academy of Management and Administration in Opole. 2020. 162 p.

14. Rogovskii I. L., Titova L. L., Trokhaniak V. I., Rosamaha Yu.O., Blesnyuk O. V., Ohiienko M. M. Ohiienko A. V. Engineering management of two-phase coulter systems of seeding machines for implementing precision farming technologies. INMATEH. Agricultural Engineering. 2019. Bucharest. Vol. 58. No 2. P. 137-146. doi: 10.35633/INMATEH-58-15.

\section{ДИСКРЕТНА МОДЕЛЬ ДИНАМІКИ РУХУ ЛАНЦЮГОВОГО КОНВЕСРА М. М. Коробко}

Анотація. У процесі пуску ланцюгових конвеєрів у тяговій ланці полотна виникають динамічні навантаження, величина яких, головним чином, залежить від надлишкової сили або тривалості пуску. Під дією імпульсів, що створюють прискорення, в елементах системи виникають малі пружні коливання. Останні приводять до зростання інерційних навантажень у порівнянні з їх середніми значеннями, які визначаються законами руху абсолютно твердого тіла. В умовах непостійності швидкостей всіх або деяких елементів машини такі величини, як тривалість періодів пуску (розгону) й гальмування, перевантаження двигуна і передач, можна визначити лише на основі динамічних розрахунків, при яких враховується як непостійність швидкості під час руху, так й інерційність мас, що беруть участь у процесі pyxy.

Також робота ланцюгових конвеєрів характеризується наявністю динамічних зусиль, що виникають у результаті пульсуючого руху ланцюга при усталеному обертанні приводної зірочки. На ділянці пуску до цих зусиль додаються динамічні зусилля від зростання швидкості з нульового значення до певної усталеної величини. За таких умов у ланцюгу можуть виникати значні знакозмінні динамічні навантаження, які в результаті накопичення втомних явищ можуть привести до передчасного його руйнування.

У роботі розроблено динамічну модель ланцюгового конвеєра, яка враховує основний рух $і$ коливання елементів приводу та робочого полотна.

Ключові слова: конвеєр, модель, маса.

\section{ДИСКРЕТНАЯ МОДЕЛЬ ДИНАМИКИ ДВИЖЕНИЯ ЦЕПНОГО КОНВЕЙЕРА

$$
\text { Н. Н. Коробко }
$$

Аннотация. В процессе пуска цепных конвейеров в тяговом звене полотна возникают динамические нагрузки, величина которых, главным образом, зависит от избыточной силы или продолжительности пуска. Под действием импульсов, создающих ускорение, в элементах системы возникают малые упругие колебания. Последние приводят к росту инерционных нагрузок по сравнению с их средними значениями, которые определяются законами движения абсолютно твердого тела. В условиях непостоянства скоростей всех или некоторых элементов машины такие величины, как продолжительность периодов пуска (разгона) и торможения, перегрузки двигателя и передач, можно определить лишь на основе динамических расчетов, при которых учитывается как непостоянство скорости во время движения, так и инерционность масс, участвующих в процессе движения.

Также работа цепных конвейеров характеризуется наличием динамических усилий, возникающих в результате пульсирующего движения цепи при установившемся вращении приводной звездочки. На участке пуска к этим усилиям добавляются динамические усилия от роста скорости с нулевого значения до определенной устоявшейся величины. При таких условиях в цепи могут возникать значительные знакопеременные динамические нагрузки, в результате накопления усталостных явлений могут привести к преждевременному его разрушению.

В работе разработана динамическая модель цепного конвейера, которая учитывает основное движение и колебания элементов привода и рабочего полотна.

Ключевые слова: конвейер, модель, маса

М. М. Коробко ORCID 0000-0002-1138-7701. 